https://helda.helsinki.fi

The importance of nesting cavity and tree reuse in the three-toed woodpecker Picoides tridactylus in dynamic forest landscapes

\title{
Pakkala, Timo
}

2017-04

Pakkala , T , Tiainen , J \& Kouki , J 2017 , ' The importance of nesting cavity and tree reuse in the three-toed woodpecker Picoides tridactylus in dynamic forest landscapes ', Annales Zoologici Fennici , vol. 54 , no. 1-4 , pp. 175-191 . https://doi.org/10.5735/086.054.0116

cc_by

publishedVersion

Downloaded from Helda, University of Helsinki institutional repository.

This is an electronic reprint of the original article.

This reprint may differ from the original in pagination and typographic detail.

Please cite the original version. 


\title{
The importance of nesting cavity and tree reuse in the three-toed woodpecker Picoides tridactylus in dynamic forest landscapes
}

\author{
Timo Pakkala ${ }^{1,2, *}$, Juha Tiainen ${ }^{3} \&$ Jari Kouki $^{2}$ \\ 1) Lammi Biological Station, University of Helsinki, Fl-16900 Lammi, Finland (" ${ }^{*}$ corresponding \\ author's e-mail: timo.pakkala@hotmail.fi) \\ 2) University of Eastern Finland, School of Forest Sciences, P.O. Box 111, FI-80101 Joensuu, \\ Finland \\ 3) Natural Resources Research Institute Finland, P.O. Box 2, FI-00791 Helsinki, Finland
}

Received 7 Nov. 2016, final version received 20 Jan. 2017, accepted 23 Jan. 2017

Pakkala, T., Tiainen, J. \& Kouki, J. 2017: The importance of nesting cavity and tree reuse in the three-toed woodpecker Picoides tridactylus in dynamic forest landscapes. - Ann. Zool. Fennici 54: 175-191.

Cavity-nesting birds can save time and energy by reusing old cavities. We studied cavity reuse and its connections to nesting success and timing in the three-toed woodpecker Picoides tridactylus in a 170-km² area in southern Finland during 1987-2015. The data include 520 nest trees, 645 nest cavities and 833 nestings in 86 territory sites, including 211 cases of cavity reuse. Twenty-five percent of nestings was in previously used cavities. Twenty-eight percent of cavities and $25 \%$ of nest trees were used more than once. Reuse improved nesting success and facilitated early nesting in the year following first nesting. Reuse of nest trees with several cavities was observed in $15 \%$ of nest trees, and $62 \%$ of reused cavities were in those multi-cavity trees. Cavity reuse and multi-cavity trees were most abundant in long-term territories with stable habitats. In boreal forests, cavity and tree reuse can be an important adaptation allowing efficient nesting during a short breeding season.

\section{Introduction}

Safe nest sites are of great importance for successful breeding of birds (Collias 1964, Hansell 2000). Cavities are preferred as nesting sites by many species, and cavity nesting species can use considerable amount of energy for excavating or improving suitable nest holes (Short 1982, Newton 1994). Time available for breeding is, however, limited, especially in northern latitudes, and cavity-excavating species can save time by reusing old nest holes. Obviously, cavity-excavating bird species are likely to face a trade-off between excavating a new cavity and reusing an old one, and the decision depends on, e.g., population structure or different risks such as predation, competition and ectoparasitism (Short 1979, Aitken et al. 2002, Wiebe et al. 2006, 2007, Mazgajski 2007a). The use of an old cavity may also be beneficial because woodpeckers have previously found it structurally sound, its location is advantageous for feeding or previous nesting attempts were successful (see Aitken \& Martin 2004, Wiebe et al. 2007). 
The advantage of reusing a cavity for nesting, however, varies in time, and also the physical properties of the cavity and nest tree change (Wiebe 2001, Mazgajski 2007b, Edworthy \& Martin 2014).

In this study, we investigated the abundance and patterns of nest and tree reuse in the threetoed woodpecker Picoides tridactylus; the species is generally considered to excavate a new cavity every year (Dementiev \& Gladkov 1966, Glutz \& Bauer 1980, Cramp 1985, Winkler \& Christie 2002, Wiebe et al. 2006). The threetoed woodpecker has a wide northern range of distribution that corresponds largely with that of spruce (Picea spp.) and larch (Larix spp.), and it prefers mature and mixed conifer forests (Dementiev \& Gladkov 1966, Winkler \& Christie 2002). The species favours forests with a good proportion of recently dead and dying trees, including fallen logs (Hess 1983, Pechacek 1995, Ruge et al. 1999, Bütler et al. 2004). The whole year around its diet predominantly consists of insects, mainly conifer bark beetles (Coleoptera, Scolytidae) or longhorn beetle larvae (Coleoptera, Cerambycidae) (Dementiev \& Gladkov 1966, Glutz \& Bauer 1980, Pechacek \& Krištín 1993, 1996), and the species also prefers dead or dying trees for nesting (e.g. Ruge 1974, Hågvar et al. 1990, Stenberg 1996, Pechacek 2001, Wesołowski 2011).

The cavity and tree reuse by the three-toed woodpecker is so far poorly known. Thus, in this study, we first explored and documented general patterns of the cavity and tree reuse by three-toed woodpeckers, using exceptionally long-term and large-scale spatially explicit data. After that we looked more closely at some specific hypotheses that traditionally used to explain general cavity and tree resuse patterns in birds, as indicated above. The following hypotheses were studied:

1. We hypothesized that cavity reuse provides a seasonal advantage for breeding pairs because time needed to excavate a cavity can be spent to other reproductive activities. If this was the case, there should be a systematic difference in the initiation of breeding (egg-laying) between fresh and reused cavity breedings.

2. We predicted that breeding success is higher in reused cavities. If this was the case, there should be a predictable effect of reuse on offspring number or survival. The most likely explanation would be the saved time and resources, thus available for raising offspring.

3. At the population level, tree reuse may be spatially variable, reflecting some environmental variation in habitat characteristics. If there were spatial patterns in the occurrence and frequency of reuse of cavities and if the reuse was connected to breeding success, we would expect that reuse of cavities and trees to be located in high-quality habitats with continuously occupied territories.

\section{Material and methods}

\section{Study area}

The study area is located within the southern boreal vegetation zone in the municipalities of Hämeenlinna, Padasjoki and Asikkala in southern Finland (around $61^{\circ} 15^{\prime} \mathrm{N}, 2^{\circ} 03^{\prime} \mathrm{E}$; Fig. 1). With a total area of $170 \mathrm{~km}^{2}$, the study area is dominated by mature, mostly managed coniferous forest stands combined with a mixture of stands of different ages and several, usually small, oligotrophic lakes. Human settlements in the area are scarce. The study area is also characterized by a relatively high small-scale topographic variation that has formed the forest landscape spatially as a mosaic of dry and moist forest habitats. Small prescribed silvicultural burnings were carried out in the area during the study period. The central part of the study area contains a few conservation areas with mature forests and buffer zones where various actions to restore especially moist spruce forests, and to increase the amount of dead wood, were carried out during the last 20 years. An introduced, local population of the North American beaver Castor canadensis has lived in the study area for over 50 years (Lahti \& Helminen 1974); it actively modifies lowland areas by flooding and increasing the amount of dead and decaying trees. In central parts of the study area owned by the state (about one third of whole study area), commercial forestry was suppressed to some extent during the last 10 years; e.g. fallen trees 
were mostly left in the forest, and the abovementioned restoring activities were carried out in various places of the area (Nordström 2015). On the other hand, clear-cut logging of mature, formerly relative continuous forest areas increased in the study area. Harvest was quite intensive in private-owned areas around the state-owned area during the last 15 years.

\section{Three-toed woodpecker nest surveys}

We searched for three-toed woodpecker nests within the study area annually during the years 1987-2015. Annual nest censuses typically lasted from early April to the middle of July. They included systematic mapping of active territories within the study area before the breeding season with efforts to locate the most potential nesting sites by observing the behaviour of woodpeckers and searching of nests during the entire breeding season. Within each territory site, nest searching was continued with systematic mapping of all potential sites if the behaviour of the woodpeckers indicated nesting. However, most effort was allocated to cavity-excavation and nestling periods when detectability of nests was better than during the egg-laying and incubation phases when visits to nest sites were limited also to avoid excess disturbance. Many nests were detected in cavity-excavation phase, but several nests, especially those located high in living trees, were not found until the nestling phase. Nests found were regularly followed during the breeding season usually by visiting them once in 1-2 weeks. During the expected fledging time, the nests were visited more frequently, to estimate the timing of nesting more exactly. In territories where the nest had not been found, we looked for fledglings to confirm nesting and to estimate its timing. All these censuses were done by the first author except during 2003-2008 when an intensive population study of the threetoed woodpecker with radio-tracking and colourringing was conducted within the study area and an additional team of five persons was involved also in the nest surveys (see Acknowledgements). Inaccuracy and bias of three-toed woodpecker censuses and their possible effects on the results are discussed in the Appendix.

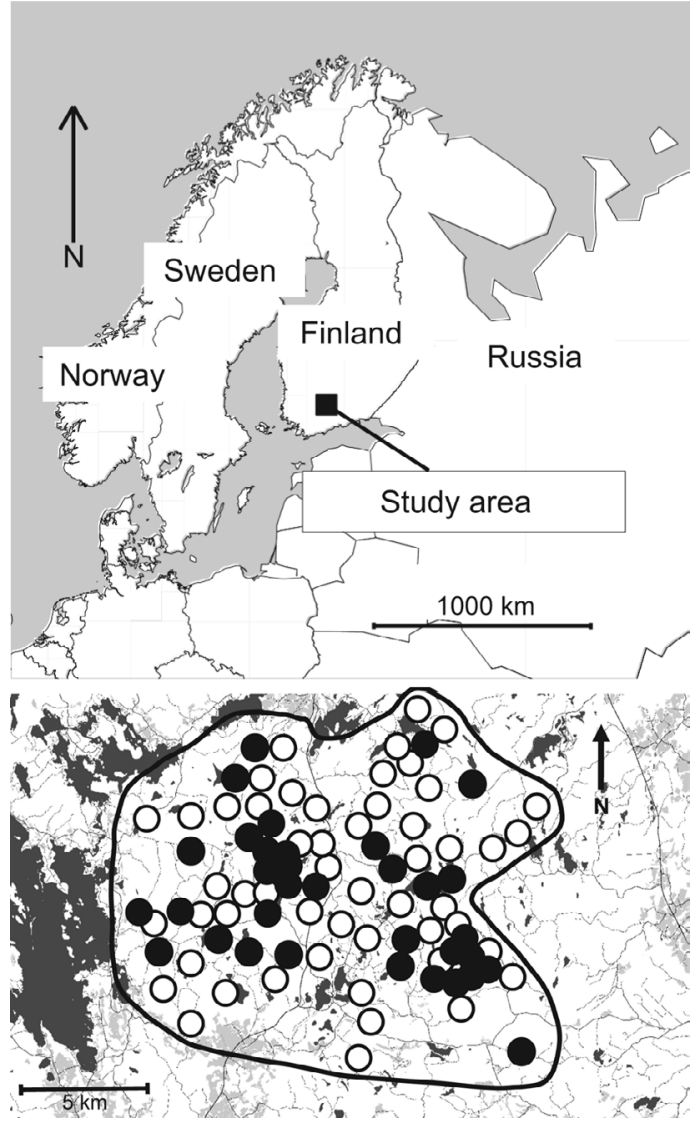

Fig. 1. Location of the study area in southern Finland (around $61^{\circ} 15^{\prime} \mathrm{N}, 25^{\circ} 03^{\prime} \mathrm{E}$; top) and the study area (bottom) with core $(0)$ and other $(\bigcirc)$ territories of the three-toed woodpecker during the study period 19872015 . Territory sites $(n=86)$ were divided into two site classes based on occupancy measures (core territory sites: $n=34$, all occupancies $>90 \%$ with mean occupancy 0.97 ; and other territory sites: $n=52$, all occupancies $<60 \%$ with mean occupancy 0.33 ). Lakes are dark gray and agricultural areas are light gray. Other areas consist mostly of forests. Roads are marked by thin lines. Note that the map does not show the complete distribution or all territory sites of the three-toed woodpecker, because only territories with active nestings observed were included in this study.

\section{Nest and nest tree data}

Locations of the nest trees were mapped and old nest trees and cavities were checked during each following study year to get information about their possible reuse by the three-toed woodpecker. Old nest trees were annually monitored in connection with nest surveys (see above) from 
the first year of three-toed woodpecker nesting until the trees were not suitable for nesting (tree fallen, broken, logged, nest cavity damaged).

The final data set included only those cases in which the three-toed woodpecker most certainly reached at least the egg-laying phase (called here 'active' nests and nestings), i.e. nesting attempts interrupted during excavation - although they included a seemingly complete nest cavity - are not included in these data. During the study, a total of 520 nest trees with 645 active nest cavities and 833 active nestings were detected during 6200 observations which included annual information on each nest cavity measured. All these data were gathered by the first author.

\section{Data of nest and tree reuse}

Data of nest reuse include observed active nestings either in old cavities made by the three-toed woodpecker itself or in other cavities. During the study, 211 cases of nest cavity reuse by the three-toed woodpecker were detected, consisting of 195 cases of nest reuse of its own cavities, 11 cases of nesting in old cavities of the great spotted woodpecker Dendrocopos major and 5 cases of nesting in nest boxes.

Nest trees were divided into single- and multicavity trees. Only trees with more than one active three-toed woodpecker nest cavity observed (fresh or reused) during the study period were classified as multi-cavity trees. Same nest tree was never used more than once during any single year. According to this classification, there were 78 multi-cavity nest trees in the data.

\section{Data on territories and territory sites}

The number and locations of three-toed woodpecker territories within the study area were investigated by mapping censuses that annually covered the breeding period from late March to early July (Pakkala et al. 2002, 2006). Annual territory locations and approximate borders were defined using information on woodpeckers and their nest sites. All annual data were then combined to estimate territory sites for the total study period. Additional field observations of locations and movements of individually marked threetoed woodpeckers within the study area in 20032010 were used to help in defining the borders between territory sites. Altogether 86 territory sites were defined within the study area during the study period (Fig. 1). All territory mappings were done by the first author.

Annual observations of nest trees within territories were combined to calculate the total numbers of multi-cavity trees and active nestings as well as the proportions of nestings in multicavity trees and in reused nest-cavities for each territory site.

\section{Data of nesting success and timing of nesting}

Nesting success was estimated as the proportion of successful active nestings to all active nestings at each study scale (nest cavity, nest tree, territory site). The nesting was classified as successful, if large nestlings ready to fledge soon or fledglings with adults in the vicinity of a recent active nest cavity were observed.

We compared timing of successful nesting among various types of cavities and in fresh cavities between single- and multi-cavity trees. Each study year was tested separately. Because the exact start of nesting was difficult to obtain, it was assessed for the same study year using the information on the size of nestlings at certain times during the breeding season and the observed and estimated dates of fledging. Instead of using estimated calendar days, all annual nestings were ranked with respect to each other. The annual significance of differences in timing of successful nesting among (i) fresh cavities, (ii) reused cavities with nesting in the successive year after the fresh or reused cavity, and (iii) reused cavities with a time-lag of two years or more after the previous nesting was evaluated with a Kruskal-Wallis test. Pairwise comparisons between the years were carried out using Dunn's test (Dunn 1964) with $p$ values adjusted for multiple comparisons with the Bonferroni correction. The differences in timing of nesting in fresh cavities between single- and multiple-cavity trees were evaluated with a Mann-Whitney $U$-test. 
Correlations between nesting success and territory characteristics were tested using Spearman rank-order correlation.

To study the timing of nesting, the highly comprehensive data from whole study area collected in 1996-2015 were used. This data subset included a total of 568 successful nestings. All the data on breeding success and timing of nesting were gathered by the first author except during 2003-2010 when additional information about the active ringing of the nestlings within the study area was also used.

\section{Territory site measures}

We used the proportion of years with territorial behaviour or nesting detected of all census years in a defined territory site as a measure of territory site occupancy. Territory site quality was measured as a proportion of years with active nestings detected to all census years with territorial behaviour or nesting detected at a defined territory site. These definitions of occupancy and quality are straightforward and the occupancy and quality values easy to calculate from the data, and they are relatively comparable between different sites because of standardized census efficiency (but see the next section). Moreover occupancy describes the overall suitability, and quality the total productivity of the territory site during the study period. It is likely that these measures combine in ecologically meaningful way the effects of forest quality, fragmentation and isolation that are not often easy to deduct from the available data.

Territory sites were divided into two classes based on territory occupancy measures: (1) 34 core territory sites, all occupancies $>90 \%$ (mean occupancy 0.97); and (2) 52 other territory sites, all occupancies $<60 \%$ (mean occupancy 0.33 ; Fig. 1). This division was also used in territory site comparisons.

\section{Results}

\section{Frequency of nest cavity reuse and abundance of multi-cavity trees}

A total of 520 nest trees were found during the study, of which 507 were original nest trees of the three-toed woodpecker. In nine trees, an old cavity of the great spotted woodpecker, and in four nest trees nest-boxes instead of a cavity were used. In two of the nest trees where old cavities of the great spotted woodpecker were used, there were also cavities of the three-toed woodpecker; these were classified as "real" nest trees of the three-toed woodpecker. The total number of observed active nest cavities was 645 that included 630 cavities excavated by the three-toed woodpecker, 11 old cavities of the great spotted woodpecker, and 4 nest boxes.

Three-toed woodpeckers reused old nest cavities rather often as a total of 211 cases were recorded: 11 of those were old cavities of the great spotted woodpecker, 5 were nest boxes, and all other 195 were old cavities of the threetoed woodpecker. Altogether 833 active nestings were observed in the study area, and thus $25.3 \%$ of nestings were situated in reused cavities. Nest reuse was observed in $28.2 \%$ of all cavities and in $25.4 \%$ of all nest trees (Table 1).

The total numbers of active nest cavities and nestings per nest tree were $1-8$ and $1-13$, respectively (Fig. 2). During the study period, there were 78 nest trees with more than one active nest cavity, hence the total proportion of multi-cavity nest trees was $15.0 \%$ (or $15.4 \%$ if only "real" nest trees are included).

The most prominent feature of the cavity reuse was that a new-excavated nesting cavity was used by the three-toed woodpecker also in the following year; there were 112 such cases amounting to $53.0 \%$ of all cavity reuses. There were also 10 cases of the nest cavity being reused also in the third year, but other type of cavity reuse during successive years was uncommon (only four cases detected). Cavity reuse was detected up to 19 years after the first nesting, and up to four active nestings in the same cavity were recorded (Fig. 2).

\section{The role of multi-cavity trees in nest reuse}

In spite of the relatively low number of nest trees (see above), in multiple-cavity trees there were in total 203 active nest cavities and 335 active nestings, which makes almost a third (31.8\%) 

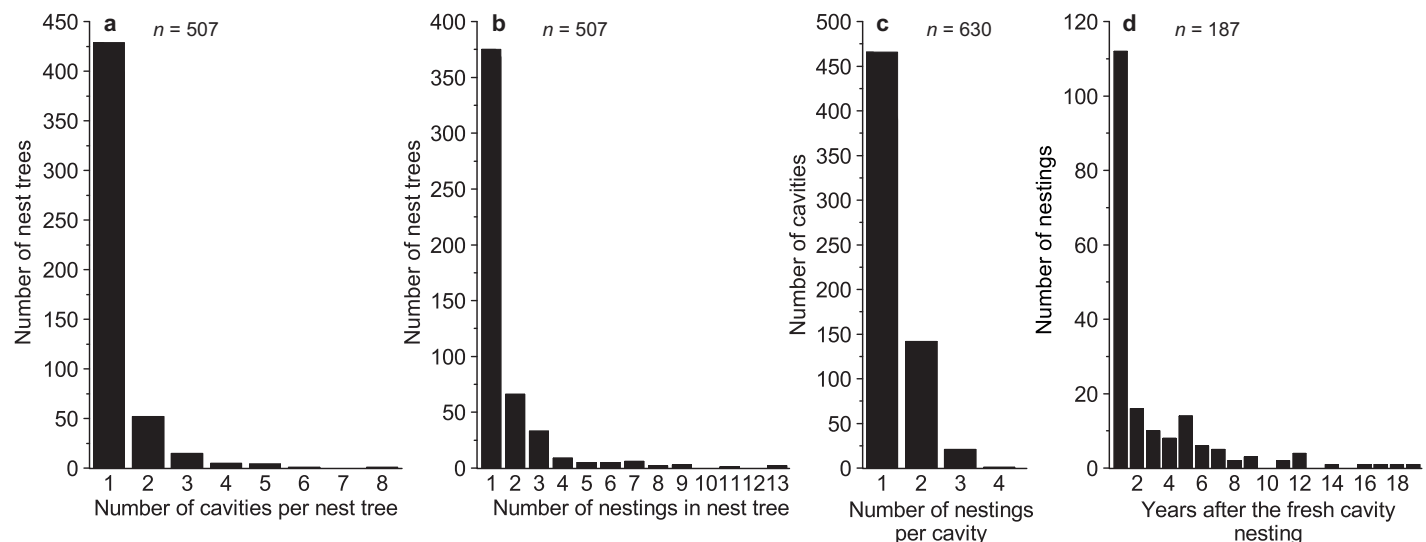

Fig. 2. Patterns of nest-tree and cavity reuse by the three-toed woodpecker: (a) cavities in nest trees, (b) nestings in nest trees, (c) nestings in cavities, and (d) nestings in cavities in time after the fresh cavity.

of all cavities and $40.2 \%$ of all nestings, respectively. The multi-cavity trees comprised $47.7 \%$ of all the trees with reused cavities, $62.1 \%$ of all reused cavities were in the multi-cavity trees, and $62.9 \%$ of all nestings were in reused cavities. The high incidence of cavity reuse in multiple-cavity trees indicates strong connection between cavity reuse and multiple-cavity trees as compared with respective incidences in singlecavity trees (see Table 1).

\section{Timing of nesting in reused cavities and in multi-cavity trees}

As revealed by the Kruskal-Wallis test, there was a significant $(p<0.05)$ difference in timing of nesting among the three different cavity types in 17 of the 20 study years (Table 2) which clearly supports our hypothesis. However, after Bonferroni correction, as a total of 20 different comparisons were made, 11 of the differences in timing were still significant. When the timing of nesting in a given year was compared between freshly excavated cavities and reused cavities (either freshly excavated or already reused in the previous year), in 8 out of the 20 years for which the comparisons were made nesting took place significantly earlier (Dunn's test: $p<0.05$ ) in the reused than in the freshly excavated cavities; those differences, however, became insignificant at the Bonferroni-corrected significance level

Table 1. The occurrence patterns of multi-cavity trees in three-toed woodpecker population. The following statistics are presented at the levels of nest trees, cavities and nestings: $N_{\text {all }}$ is the number of all units in the study, $N_{\text {multi }}$ is the number of multi-cavity trees or units in multi-cavity trees, multi\% $=N_{\text {multi }} / N_{\text {all }} \times 100$ is the percentage of multi-cavity trees or units in multi-cavity trees, $N_{\text {reused }}$ is the number of units with reuse observed, re\% $=N_{\text {reused }} / N_{\text {all }} \times 100$ is the percentage of units with reuse observed, $N_{\text {re+mul }}$ is the number of multi-cavity units with reuse observed, remulti\% $=$ $N_{\text {re+mul }} / N_{\text {reused }} \times 100$ is the percentage of units with reuse observed in multi-cavity trees of all units with reuse observed, $P_{\text {re,mul }}=N_{\text {re+mul }} / N_{\text {multi }}$ is the incidence of multi-cavity units with reuse observed in all multi-cavity units, and $P_{\text {re,single }}=\left(N_{\text {reused }}-N_{\text {re+mul }}^{\text {re,mul }}\right) /\left(N_{\text {all }}-N_{\text {multi }}\right)$ is the incidence of single-cavity units with reuse observed in all single-cavity units. The high incidence $(P)$ levels of cavity reuse in multiple-cavity trees describe strong relation between cavity reuse and multiple-cavity trees as compared with single-cavity trees: at the tree level: $P_{\text {re,mul }}=0.80$ vs. $P_{\text {resingle }}=$ $0.16, z=12.2, p<0.001$; at the cavity level: $P_{\text {re,mul }}=0.56$ vs. $P_{\text {re,single }}=0.16, z=10.5, p<0.001$; at the nesting level: $P_{\text {re,mul }}=0.66$ vs. $P_{\text {re, single }}=0.15, z=8.80, p<0.001$.

\begin{tabular}{lrrrrrrrrr}
\hline Level & $N_{\text {all }}$ & $N_{\text {multi }}$ & multi\% & $N_{\text {reused }}$ & re\% & $N_{\text {re+mul }}$ & remulti\% & $P_{\text {re,mul }}$ & $P_{\text {re,single }}$ \\
\hline Nest trees & 520 & 78 & 15.0 & 132 & 25.4 & 63 & 47.7 & 0.80 & 0.16 \\
Cavities & 645 & 203 & 31.8 & 182 & 28.2 & 113 & 62.1 & 0.56 & 0.16 \\
Nestings & 833 & 335 & 40.2 & 211 & 25.3 & 139 & 65.9 & 0.66 & 0.15 \\
\hline
\end{tabular}


$(p<0.0025)$. The nestings in reused cavities with a time-lag of two years or more after the previous nesting began generally later than both nestings in fresh cavities (Dunn's test: $p<0.05$, 8 cases; $p<0.0025,5$ cases) and nestings in reused cavities in the successive year after the fresh or reused cavity (Dunn's test: $p<0.05,12$ cases; $p<0.0025,4$ cases) (Table 2 ).

Nestings in multi-cavity trees began earlier than in single-cavity trees in each of the 20 study years; and based on the results of the MannWhitney $U$-test, there were $12(p<0.05)$ and 5 $(p<0.0025)$ significant between-year differences in timing of the nesting (Table 2). Thus there was a general tendency for earlier nesting in multicavity trees than in single-cavity trees when threetoed woodpecker nested in fresh cavities.

\section{Nesting success in reused cavities and in multi-cavity trees}

Nesting success was generally rather high; $90.9 \%$ of all the active nestings $(n=833)$ and $90.0 \%$ of active nestings in cavities excavated by the three-toed woodpecker $(n=817)$ were successful. There were differences in nesting success between new and old cavities: in all new cavities $(n=622)$ it was $89.9 \%$, but in all old cavities $(n=211)$ and in old three-toed woodpecker's cavities $(n=195)$ it was $93.8 \%$ and $94.4 \%$, respectively. The differences were statistically nearly significant (test of two proportions: all new versus all old: $z=1.73, p=0.08$; all new versus all old three-toed: $z=1.91, p=0.06$ ), again supporting our hypothesis.

The nesting success in the second-year old cavities of the three-toed woodpecker $(n=112)$ was $97.3 \%$, which was significantly higher than in new cavities $(z=2.54, p=0.01)$ or in all other old cavities (nesting success $90.4 \%, n=83, z=$ $2.08, p=0.04)$.

There was a clear dependence between nesting success in the previous year and the reuse of cavity in the following year: in all cases $(n=$ 126) successive nesting in the same cavity in the following year was preceded by successive nesting in the previous year. In other cases of reuse of three-toed woodpecker cavities $(n=69)$, only two nestings were detected in cavities where nesting had previously been unsuccessful. This points out the link between the history of the nest site and its future reuse.

The total success of active three-toed woodpecker nestings in multi-cavity trees $(n=335)$ was $94.3 \%$, whereas nestings in single-cavity trees $(n=498)$ was successful only in $88.6 \%$ of the cases; the difference was statistically significant $(z=2.84, p=0.005)$. There was also a statistically significant difference in nesting success in new cavities and no difference in nesting success in reused ones when comparing multi- and single-cavity trees [new cavities in multi-cavity trees ( $n=196$, nesting success $93.9 \%)$ versus new cavities in single-cavity trees $(n=426$, nesting success $88.0 \%$ ) trees: $z=2.25, p=0.025$; reused

Table 2. Patterns of timing of successful nestings in various types of cavities and nest-trees during the study period of 20 years (1996-2015).

Comparisons of differences in

timing of successful nestings
Type of difference observed
No. of years that differed significantly

at $p<0.05$ at Bonferroni-corrected $p<0.0025$

Timing of nesting in fresh, reused successive,
and lag-reused cavities
Difference between fresh and reused successive
cavities
Difference between reused successive and
lag-reused cavities
Difference between fresh and lag-reused
cavities
Timing of nesting in single- and multi-cavity
trees

General difference
in timing
Reused successive
cavities earlier
Reused successive
cavities earlier
Fresh cavities
earlier
Multi-cavity trees
earlier


cavities in multi-cavity trees ( $n=139$, nesting success $95.0 \%$ ) versus reused cavities in singlecavity trees $(n=72$, nesting success $91.7 \%)$ trees: $z=0.94, p=0.35]$. The better overall nesting success in multi-cavity trees thus results from both better nesting success in new cavities and much greater incidence of reused cavity nestings with high nesting success as compared with that in single-cavity trees (Table 1).

\section{Nest and tree reuse and nesting success at territory level}

There was a positive correlation between territory occupancy and proportion of nestings in reused cavities (Spearman's correlation: $r_{\mathrm{s}}=$ $0.76, p<0.001, n=86$ ), and territory occupancy and proportion of nestings in multi-cavity trees $\left(r_{\mathrm{S}}=0.71, p<0.001, n=86\right)$. However, we did not detect any dependency between territory occupancy and nesting success $\left(r_{\mathrm{S}}=0.03, p=\right.$ $0.80, n=86$ ). On the other hand, there was a positive correlation between territory occupancy and total number of successful nestings $\left(r_{\mathrm{s}}=\right.$ $0.93, p<0.001, n=86)$, and also between territory occupancy and quality $\left(r_{\mathrm{S}}=0.62, p<0.001\right.$, $n=86$ ) that emphasize the importance of territories which are frequently occupied as compared with short-term territory sites.

When all territory sites $(n=86)$ were classified as either almost continuously occupied core territories $(n=34$, mean occupancy $=0.97)$ or other territories ( $n=52$, mean occupancy $=0.33)$, proportions of nestings both in reused cavities and in multi-cavity trees were significantly higher in core territories, which indicates a spatial effect and supports our hypothesis. In core territories, $29 \%$ of all active nestings were in reused cavities and almost half of them (48\%) in multi-cavity trees, but in other territories the respective proportions were only $8 \%$ and $9 \%$, respectively. Territory quality was also significantly better in core territories than in other territories, but there was no significant difference in nesting success between the territory types (Table 3 ).

\section{Discussion}

In our study, we found that cavity and tree reuse were quite common in the three-toed woodpecker. Furthermore, the specific hypotheses we stated received clear support. Based on the results we conclude that (1) reuse allows a pair to initiate breeding earlier, (2) nesting success is better in reused cavities than in fresh cavities, and (3) reuse of cavities is more frequent in core population area suggesting that reuse is related to territory and habitat quality.

\section{Reuse or excavate?}

Why should woodpeckers reuse old cavities and nest trees instead of excavating in a new nest tree? One obvious reason would be saving time and energy which is needed to excavate a cavity and allocating it to e.g. feeding or resting. According to Sollien et al. (1978) the three-toed woodpecker needs 12 days to complete a hole. In our study area, in five cases when cavity excavation could be followed from the early start to completion the time needed varied between

Table 3. Characteristics of three-toed woodpecker territories. All territory sites $(n=86)$ were divided to more or less continuously occupied core territories and other territories. Mean territory quality and nesting success as well as mean proportions of nestings in old cavities $\left(\right.$ prop $_{\text {reused }}$ ) and in multi-cavity trees $\left(\right.$ prop $_{\text {multi }}$ ) are also presented. These territory measures were calculated as arithmetic means of respective single territory values. There was a significant difference in territory quality, prop $_{\text {reused }}$ and prop $_{\text {multi }}$ between core and other territories but the difference in nesting success was not significant (Mann-Whitney $U$-test: territory quality: $U=212.0$, prop $_{\text {reused }}: U=168.5, \operatorname{prop}_{\text {multi: }} U=$ 203.5, $p<0.001$ for all cases; nesting success: $U=861.5, p=0.84$ ).

\begin{tabular}{lcccccc}
\hline Territory site & $N$ & Occupancy & Territory quality & Nesting success & Prop $_{\text {reused }}$ & Prop $_{\text {multi }}$ \\
\hline Core & 34 & 0.97 & 0.74 & 0.92 & 0.29 & 0.48 \\
Other & 52 & 0.33 & 0.50 & 0.85 & 0.08 & 0.09 \\
All & 86 & 0.59 & 0.60 & 0.88 & 0.16 & 0.24 \\
\hline
\end{tabular}


8 and 18 days (median of 11 days; T. Pakkala unpubl. data). Woodpeckers differ in the selection of nest tree species and condition, and thus the effort required to excavate a new cavity varies between woodpecker species (Short 1979, Winkler \& Christie 2002, Wiebe et al. 2007).

Many woodpecker species, including the three-toed woodpecker, are known to excavate several unfinished cavities each spring before the actual nesting cavity is made ready (Blume 1968, Ruge 1974, Cramp 1985, Pechacek \& d'Oleire-Oltmanns 2004, Pakkala et al. 2006). Old, unfinished cavities can be completed even several years later and turned to nesting cavities (Blume 1968, Ivanchev 1997, Rolstad et al. 2000, Matsuoka 2010). In three cases when the time three-toed woodpeckers needed to complete old, unfinished cavities could be accurately estimated by observation, the excavation took 5,7 and 8 days (T. Pakkala unpubl. data). These times were significantly shorter than needed to excavate a new cavity, but the excavation time varies much depending on the completeness of the old cavity.

The three-toed woodpecker and many other woodpecker species commonly start to excavate several holes in the same tree (Schifferli \& Ziegeler 1956, Blume 1968, Ruge 1974, Pakkala et al. 2006, Matsuoka 2010). These "trial holes" are probably excavated to test the suitability of the nest tree, especially its hardness (Matsuoka 2008, 2010, Lorentz et al. 2015). In our study, unfinished cavities and trial holes were especially common in multi-cavity trees, and they were regularly used as templates for new cavities. The use of unfinished cavities and trial holes can save some excavation time, but also less time and energy is needed to search and test suitable places for cavities (e.g. Short 1979). In any case, as considerable effort is allocated to cavity excavation, individuals using old cavities may profit from nesting earlier or being in better condition which may increase their nesting success.

Why do woodpeckers then use so much energy and time to excavate a new cavity? One important reason is that quality of old cavities decreases in time (Wiebe 2001, Edworthy \& Martin 2014). Also life-span of nest trees is limited; cavities in living trees whose wood is hard may generally be suitable for much longer than those in dead or decaying trees (Wesołowski
2011, Blanc \& Martin 2012, Edworthy et al. 2012). If suitable old cavities are available, decisions made by birds whether to reuse a cavity or excavate a new one depend on what the costs and benefits of these two options are. The outcome is seen at the population level as proportions of cavity reuse by woodpecker species.

\section{Cavity and tree reuse patterns in the three-toed woodpecker and its relatives}

We detected quite high proportions of cavity $(25.3 \%)$ and tree $(15.0 \%)$ reuse by three-toed woodpecker considering that in earlier studies this behaviour was seen as occasional (e.g. Svärdson \& Durango 1950, Haftorn 1971, Winkler \& Christie 2002). Scattered observations of three-toed woodpeckers breeding in nest-boxes exist (Hortling 1929, von Haartman et al. 19631972, Ryssy 2004, Bolund 2010), indicating its potential to use old cavities. However, Wiebe et al. (2006) did not detect any cavity reuse in the three-toed woodpecker or in the American threetoed woodpecker Picoides dorsalis. In southern Finland, cavity reuse proportions of $5 \%-10 \%$ were found in three-toed woodpecker populations in the areas neighbouring that of our study (H. Lokki pers. comm., T. Nurmi pers. comm., P. Pouttu pers. comm.).

Also the North American black-backed woodpecker Picoides arcticus, a close relative of the three-toed woodpecker, reuses cavities although at smaller rates than what we found (2.8\%-7.1\%; Dixon \& Saab 2000, Saab et al. 2004, Wiebe et al. 2006). Of the north European woodpecker species, cavity reuse has commonly been observed in the black woodpecker Dryocopus martius and the great spotted woodpecker (Dementiev \& Gladkov 1966, Glutz \& Bauer 1980, Cramp 1985). The variation in the proportion of reuse between different populations of these species was rather large (cf. Wiebe et al. 2006). In studies at northern latitudes with large data sets, the cavity reuse proportions were very near our results: in the black woodpecker $26.0 \%$ in southern Sweden $(n=264$; Nilsson et al. 1991) and 30\% in central Norway ( $n=106$; Rolstad et al. 2000), and in the great spotted woodpecker $25.8 \%$ in western Russia ( $n=198$; 
Ivanchev 1997) and 21.4\% in southern England $(n=135$; Smith 1997). However, in a large data set on the black woodpecker in southern Finland ( $n=300$; P. Pouttu pers. comm.) the cavity reuse was even more common (ca. 60\%) than excavating new cavities.

In general there are only few studies on multi-cavity trees of northern woodpecker species. In the well-studied woodpecker species multi-cavity trees have commonly been observed e.g. in the northern flicker Colaptes auratus (e.g. Lawrence 1967, Moore 1995, Fisher \& Wiebe 2005), great spotted woodpecker (proportions of multi-cavity trees between $8 \%-49 \%$; Hågvar et al. 1990, Hansson 1992, Glue \& Boswell 1994, Stenberg 1996, Mazgajski 1998), and black woodpecker (25\%-47\%; Hågvar et al. 1990, Rolstadt et al. 2000, Kosiński et al. 2011). Nest tree reuse has been occasional or absent in the three-toed woodpecker in central Europe (Pechacek 2001, Pechacek \& d'Oleire-Oltmanns 2004, P. Pechacek pers. comm., K. Ruge pers. comm.) or in eastern Finland (P. Fayt pers. comm., J. Lakka \& T. Nurmi pers. comm.). In southern Finland proportions of $15 \%-20 \%$ were found in areas near our study area (J.Ahola \& M. Nääppä pers. comm., P. Pouttu pers. comm.), and Stenberg (1996) found a proportion of $20 \%$ of nest tree reuse in western Norway. Although the big picture is not clear because of the scarcity of population studies of the three-toed woodpecker, the structure and dynamics of forest environment may play role in the proportion of cavity and tree reuse at the territory and population levels, a topic discussed in the last section of this paper.

\section{Three-toed woodpeckers in old cavities and nest trees}

Early breeding has generally been considered to correlate positively with a larger number of offspring in various bird groups (Perrins 1970, Nilsson \& Smith 1988), a pattern observed also in woodpeckers (e.g. Hogstad \& Stenberg 1997, Wiktander et al. 2001, Fayt 2003, Mazgajski 2002, Pechacek 2006, Smith 2006). Wiebe et al. (2007) found that in 6 out of 8 population studies average laying dates were earlier in reused cavities, but only two of the differences were statistically significant, partly because of small sample sizes. Cavity reuse may offer a rapid adjustment to varying conditions during the breeding season. For example, in a large study of the northern flicker during 1998-2006 (a total of 1006 nesting attempts with cavity reuse of 63.1\%; Wiebe et al. 2006, 2007) there was no difference in the timing of first nests between new and reused cavities, but a greater proportion of second nests were in old cavities.

In our study, three-toed woodpecker nestings in reused cavities represented two types: (1) nesting in a cavity which was either excavated or reused in the previous year, and (2) nesting with a time-lag of two years or more after the previous nesting. In group 1 nestings were early and very successful, but in group 2 very late with nesting success at the level of fresh cavities. These types are connected to quite different situations: in (1), there was cavity reuse after a successful previous-year nesting, but in (2), there were usually some problems with commencement of nesting or the first nesting attempt was interrupted. Usually several factors simultaneously affect a cavity nester's decision whether to excavate a cavity or reuse an old one and possible timing of nesting initiation. Accordingly differences in nesting success between fresh and reused cavities should be compared in a proper context. For example, in case of group 2 the nestings are expected to be late and nesting success usually below average. However, the cavity reuse may allow the three-toed woodpecker to adjust nesting time more efficiently within the breeding season, because time needed to find suitable cavities and for excavating can be saved.

The majority of nestings in reused cavities were in second year's cavities after a successful nesting in the first year. If nesting in a fresh cavity was unsuccessful, the cavity was not used in the successive year and very rarely even in the later years. Based on the observations of colour-ringed birds, mostly same individuals used the cavity in successive years indicating that a memory of the history of the nest cavity has an effect. This pattern is consistent with results of studies of various cavity-nesting bird species, e.g. the goldeneye Bucephala clangula (Dow \& Fredga 1983), Tengmalm's owl Aegolius funereus (Sonerud 1985), black woodpecker 
(Nilsson et al. 1991), pied flycatcher Ficedula hypoleuca (von Haartman 1949), and great tit Parus major (Harvey et al. 1979).

As previously discussed, nest trees decay in time and quality of cavities decreases. Although we had no information on quality of the threetoed woodpecker's cavities, it can generally be assumed that second year's cavities are rather similar in quality to fresh ones. The cavity reuse patterns in our study and similar patterns observed in those few other studies of woodpeckers with information on long-term use of cavities indicate that reuse patterns reflect general cavity condition patterns after excavation. Ivanchev (1997) detected $80.0 \%$ (24 of 30) of reused nestings of the great spotted woodpecker in second year's cavities, and Smith (1997) respectively $41.4 \%$ (12 of 29) in second and $34.5 \%$ (10 of 29) in third year's cavities, but the possible timing and nesting success were not compared among different types of reused cavities in those studies. Pekka Pouttu (pers. comm.) estimated that at least $50 \%$ of the observed cavity reuses by the black woodpecker concerned second year's cavities. There is, however, individual variation in nest tree and cavity decay times, and reuses observed several years after excavation show that part of the cavities still remained in suitable condition for the threetoed woodpecker over long periods. We did not analyze properties of nest trees in this study, but several trees which were continuously used and majority of multi-cavity trees were middle-sized living Norway spruce, Picea abies, located usually in glens dominated by spruce swamps ( $\mathrm{T}$. Pakkala unpubl. data). In this type of environment nest trees often remain standing and are in proper condition for adequate long-term use.

Nestings in fresh cavities began earlier in multi-cavity than in single-cavity trees. We think that this may result from a regular use of unfinished cavities or trial holes in multi-cavity trees as templates for creation of new cavities, which enables a more rapid commencement of nesting than in new nest trees, because less time is needed for seeking suitable nest places and excavating a cavity from the beginning. Nesting success was better in multi-cavity trees than in trees with single cavity. Nesting during successive years in new cavities was detected in many multi-cavity trees when previous year's nesting in the same tree was successful. This pattern, quite similar to successive nesting in the same cavity described above, can partly explain the better nesting success both in fresh and all cavities of multi-cavity trees as compared with respective nestings in trees with a single cavity. Although trees with old cavities attract attention of woodpeckers, and three-toed woodpeckers regularly visited old nest trees within their territory during the breeding season, it has also been argued that hole-nesting bird species may avoid multi-cavity trees for nesting as they may be perceived as low quality trees; e.g. such trees are at risk of falling or getting damaged (Aitken \& Martin 2004). Predation risk (see below) or interference competition (Hågvar et al. 1990 and below) can also decrease the use of old nest trees. However, if the nesting place is safe and nest tree still suitable for cavity excavation, new cavities in an old nest tree can in the long run be a better option than reuse of old cavities which may have decreased in quality.

Old cavities are presumed to be more susceptible to predation than freshly excavated ones because predators may have learned their locations (Sonerud 1985, 1989). For example in the black woodpecker, nest predation by pine marten Martes martes was more frequent in reused cavities than in new ones (Nilsson et al. 1991). However, Wiebe et al. (2007) reviewed studies on cavity nesting birds and did not find any clear differences in nesting success between fresh and reused cavities. Nesting success of northern flickers was slightly better in new cavities (Wiebe et al. 2007), and the success of the great spotted woodpecker either did not differ between fresh and reused cavities (Ivanchev 1997, Mazgajski 2002) or was slightly better in reused cavities (Smith 1997). Rolstad et al. (2000) did not detect a difference in predation rates between old and new cavities in the black woodpecker, and the rates did not correlate with the number of old holes adjacent to the nests. The new-cavity excavation process may also provide cues to potential nest predators, a subject that has so far not been studied (e.g. Wiebe et al. 2007).

Ectoparasitism has been considered an important negative factor in bird nest reuse (e.g. Loye \& Zuk 1991, Møller 1997), also in cavity- 
nesting species (Mazgajski 2007a, Wiebe 2009). Changing of a nest site could reduce parasitism rates (Collias \& Collias 1984, Hansell 2000), and woodpeckers could avoid parasites by excavating new cavities (Short 1979). However, there are only few studies about the significance of ectoparasitism in bird species breeding in natural cavities (cf. Wesołowski \& Stańska 2001, Tomảs et. al. 2007); these studies do not show clear differences between freshly excavated and reused cavities (Wiebe 2009). As woodpeckers do not bring extra nest material to cavities and clean reused cavities before breeding (e.g. Short 1982, Winkler \& Christie 2002), also the difference in ectoparasite pressure between fresh and reused cavities is probably small.

We had no exact data on the causes of nest losses or interruption of nestings, but based on the field observations unfavourable, cold and rainy weather and interference of the great spotted woodpecker were the most obvious ones (Pakkala et al. 2006, see below). In some cases nesting was interrupted because the nest tree had fallen due to heavy winds or the other adult bird had died during the nesting. Observed cases in which most potential nest predators, small mustelids Mustela ssp., red squirrel Sciurus vulgaris, pygmy owl Glaucidium passerinum or great spotted woodpecker (Glutz \& Bauer 1980, Pakkala et al. 2006) could have been involved were rare, and we think that nest predation may not be a very important factor lowering nesting success. As nesting success was in general high, we think that in our study area predation risk probably plays a minor role in cavity or tree reuse by the three-toed woodpecker, although predation rates may be underestimated especially in early nesting phases. However, predation risk may vary geographically and be more important e.g. in southern populations of the species in central Europe where cavity or tree reuse has been found to be very rare (Pechacek 2001, 2006, Ruge 1974, P. Pechacek pers. comm., K. Ruge pers. comm., T. Wesołowski pers. comm.).

Cavity and interference competition with other cavity-nesting bird species can affect nesting success and timing of nesting of the threetoed woodpecker (Pakkala et al. 2006), and may also affect cavity reuse. Few studies documented that starlings Sturnus vulgaris take over freshly excavated woodpecker holes or that other secondary cavity nesters aggressively compete for existing cavities (Glutz \& Bauer 1980, Cramp 1985, Mazgajski 2003, Wiebe 2003, Fisher \& Wiebe 2005, Smith 2006). The starling is a rare breeding bird in our study area, and it was not observed to use three-toed woodpecker's cavities, but the pygmy owl and great spotted woodpecker are common cavity-nesting species at three-toed woodpeckers nest sites (Pakkala et al. 2003 , 2006). Both of them generally start nesting earlier than the three-toed woodpecker, and thus they were rarely observed to take over fresh cavities but instead regularly used old cavities of the three-toed woodpecker. The pygmy owl and great spotted woodpecker preferred multi-cavity trees when they used old three-toed woodpecker cavities, and especially the pygmy owl often used the same nest tree during many successive years (T. Pakkala unpubl. data), thus making its use impossible for the three-toed woodpecker. The negative effects of these species are thus most probably due to interference with the threetoed woodpecker that may lead to shifts in nest site location and late nesting with the general consequence of increased cavity reuse but decreased nesting success.

\section{Cavity and tree reuse at territory and population levels: adaptations in dynamic forest landscape}

We detected substantial spatial variation in cavity and tree reuse in our study population. This aspect of cavity reuse has not been studied before in forest-dominated landscapes. The most prominent feature was the difference between core and other territories; the cavity and tree reuse were significantly more common in longterm core territories occupied almost continuously. The relatively large proportions of cavity and tree reuse are interesting because the threetoed woodpecker is generally considered a species adapted to disturbance dynamics in northern boreal forests (e.g. Winkler \& Christie 2002, Fayt et al. 2005). Disturbances like windfalls, forest fires and floods create biotopes with dead and decaying wood suitable for saproxylic beetles making those areas favourable for the three- 
toed woodpecker. Suitable effects of disturbances may often be short-termed and three-toed woodpeckers then have to move to new areas. This kind of spatially variable environment may enhance excavation of new cavities near food resources.

Earlier studies in our area revealed significant positive correlations between the probability of territory occupancy and forest age, structural diversity and small-scale heterogeneity at various spatial scales (Pakkala et al. 2002, 2006, 2014). Competitors for nest holes, the pygmy owl and great spotted woodpecker (see previous section), were also common especially in long-term territories (Pakkala et al. 2003, 2006) but probably the structural complexity and high amount of nest holes and multi-cavity trees allowed coexistence of competing species and offered better possibilities for the three-toed woodpecker to use old cavities as compared with short-term territories. As cavity reuse was very common especially in core territories of our study, it may be linked to population structure of the three-toed woodpecker and also indicate overall quality of territories.

Core territory sites of the three-toed woodpecker show that even in a dynamic forest landscape some parts may remain relatively undisturbed even over longer periods. As described earlier, various disturbances affected the forest landscape in our study area before and during the study period. However, in many cases the spatial scales of the processes creating favourable areas for the three-toed woodpecker were considerably smaller than its territory size and they were often located within or close to old territory sites. Observations of radio-tracked three-toed woodpeckers also reveal that commonly used feeding places can be at relatively long distances from nest sites (Pechacek 2004, Pakkala et al. 2005). Thus in this kind of an environment, especially in areas of core territories, changes in the nesting location are not necessarily needed, and cavity or tree reuse may be a good option for nesting.

Since the numerical response of a three-toed woodpecker breeding population to favourable disturbances in forest landscape can be considerable (see Fayt et al. 2005), recruits from outside the local population must be involved. In such cases spatial scales of disturbances were usually larger than in our study, even tens or hundreds of square kilometers. We should expect a high proportion of nesting in freshly excavated cavities when three-toed woodpeckers settle down in new areas, but depending on the length of the disturbance, affecting e.g. availability of food items, cavity reuse may later be beneficial near food resources.

The ability to use old cavities and nest trees is an important adaptation of the three-toed woodpecker in dynamic forest landscapes. However, the role of reuse in population development and persistence of the species in various forest environments has not yet been studied. Although our observations of cavity and tree reuse being associated with early nesting and high nesting success emphasize their significance, we must bear in mind that the reuse proportion in any population of the species depends on the relative amounts, distribution and sizes of more stable and disturbed forest areas that can vary considerably in different types of forest environments.

\section{Acknowledgements}

We thank an anonymous reviewer for comments on the manuscript and Jorma Ahola, Philippe Fayt, Johanna Lakka, Heikki Lokki, Tomasz Mazgajski, Toni Nurmi, Mikko Nääppä, Peter Pechacek, Pekka Pouttu, Klaus Ruge, Tomasz Wesołowski and Karen Wiebe for comments and unpublished information on the study species. Heikki Pakkala helped in checking the Russian literature. The three-toed woodpecker study team Johanna Lakka, Toni Nurmi, Markus Piha, Jarmo Piiroinen and Ville Vepsäläinen is greatly acknowledged for assistance in the field work during 2003-2008. The Lammi Biological Station provided excellent facilities to TP during the field seasons. TP was financially supported by the Finnish Foundation for Nature Conservation.

\section{References}

Aitken, K. E. H. \& Martin, K. 2004: Nest cavity availability and selection in aspen-conifer groves in a grassland landscape. - Can. J. For. Res. 24: 2099-2109.

Aitken, K. E. H., Wiebe, K. L. \& Martin, K. 2002: Nest-site reuse patterns for a cavity-nesting bird community in interior British Columbia. - Auk 119: 391-402.

Blanc, L. A. \& Martin, K. 2012: Identifying suitable woodpecker nest trees using decay selection profiles in trembling aspen (Populus tremuloides). - For. Ecol. Manage. 286: 192-202.

Blume, D. 1968: Die Buntspechte (Gattung Dendrocopos). 
- A. Ziemsen Verlag, Wittenberg, Lutherstadt.

Bolund, L. 2010: Fågelholkar \& vanliga holkfåglar. - ICA, Västerås.

Bütler, R., Angelstam, P., Ekelund, P. \& Schlaepfer, R. 2004: Dead wood threshold values for the three-toed woodpecker presence in boreal and sub-Alpine forest. - Biol. Cons. 119: 305-318.

Collias, N. E. 1964: The evolution of nests and nest-building in birds. - Am. Zool. 4: 175-190.

Collias, N. E. \& Collias, E. C. 1984: Nest building and bird behavior. - Princeton University Press, Princeton.

Cramp, S. (ed.) 1985: Handbook of the birds of Europe, the Middle East and North Africa, vol. 4. - Oxford University Press, Oxford.

Dementiev, G. P. \& Gladkov, N. A. (eds.) 1966: Birds of the Soviet Union, vol. 1. - Israel Program for Scientific Translations, Jerusalem.

Dixon, R. D. \& Saab, V. A. 2000: Black-backed woodpecker Picoides arcticus. - In: Poole, A. \& Gill, E. (eds.), The birds of North America no. 509. The Academy of Natural Sciences, Philadelphia, and American Ornithologists' Union, Washington, DC.

Dow, H. \& Fredga, S. 1983: Breeding and natal dispersal of the goldeneye, Bucephala clangula. - J. Anim. Ecol. 52: 681-695.

Dunn, O. J. 1964: Multiple comparisons using rank sums. Technometrics 6: 241-252.

Edworthy, A. B., Wiebe, K. L. \& Martin, K. 2012: Survival analysis of a critical resource for cavity nesting communities: patterns of tree cavity longevity. - Ecol.Appl. 22: $1733-1742$.

Edworthy, A. B. \& Martin, K. 2014: Long-term dynamics of the characteristics of tree cavities used for nesting by vertebrates. - For. Ecol. Manage. 334: 122-128.

Fayt, P. 2003: Time of natal dispersal and reproductive decisions of the three-toed woodpecker under varying food conditions. - Forschungsbericht Nationalpark Berchtesgaden 48: 35-48.

Fayt, P., Machmer, M. M. \& Steeger, C. 2005: Regulation of spruce bark beetles by woodpeckers - a literature review. - For. Ecol. Manage. 206: 1-14.

Fisher, R. J. \& Wiebe, K. L. 2005: Nest site attributes and temporal patterns of northern flicker nest loss: effects of predation and competition. - Oecologia 147: 744-753.

Glue, D. E. \& Boswell, T. 1994: Comparative nesting ecology of the three British breeding woodpeckers. - Brit. Birds 87: 253-269.

Glutz von Blotzheim, U. N. \& Bauer, K. M. 1980: Handbuch der Vögel Mitteleuropas, vol. 9. - Akademische Verlagsgesellschaft, Frankfurt a.M.

Haftorn, S. 1971: Norges fugler. - Universitetsforlaget, Oslo.

Hågvar, S., Hågvar, G. \& Mønness, E. 1990: Nest site selection in Norwegian woodpeckers. - Holarctic Ecol. 13: $156-165$

Hansell, M. H. 2000: Bird nests and construction behaviour. - Cambridge University Press, Cambridge.

Hansson, L. 1992: Requirements by the great spotted woodpecker Dendrocopos major for a suburban life. - Ornis Svecica 2: 1-6.
Harvey, P. H., Greenwood, P. J. \& Perrins, C. M. 1979: Breeding area fidelity of great tits (Parus major). $-J$. Anim. Ecol. 48: 305-313.

Hess, R. 1983: Verbreitung, Siedlungsdichte und Habitat des Dreizehenspechtes Picoides tridactylus im Kanton Schwyz. - Orn. Beob. 80: 153-182.

Hogstad, O. \& Stenberg, I. 1997: Breeding success, nestling diet and parental care in the white-backed woodpecker Dendrocopos leucotos. - J. Orn. 138: 25-38.

Hortling, I. 1929: Ornitologisk handbok. - J. Simelii arvingar, Helsingfors

Ivanchev, V. P. 1997: Multiple use of breeding cavities by the great spotted woodpecker Dendrocopos major. - Russian J. Orn. 9: 3-5.

Kosiński, Z., Bilińska, E., Dereziński, J. \& Kempa, M. 2011: Nest-sites by stock doves Columba oenas: what determines their occupancy? - Acta Orn. 46: 155-163.

Lahti, S. \& Helminen, M. 1974: The beaver Castor fiber (L.) and $C$. canadensis (Kuhl) in Finland. - Acta Theriologica 19: 177-189.

Lawrence, L. K. 1967: A comparative life-history study of four species of woodpeckers. - Orn. Monogr. 5: 1-156.

Lorenz, T. J., Vierling, K. T., Johnson, T. R. \& Fisher, P. C. 2015: The role of wood hardness in limiting nest site selection in avian cavity excavators. - Ecol. Appl. 25: 1016-1033.

Loye, J. E. \& Zuk, M. 1991: Bird-parasite interactions: ecology, evolution and behavior. - Oxford University Press, Oxford

Matsuoka, S. 2008: Wood hardness in nest trees of the great spotted woodpecker Dendrocopos major. - Ornithological Science 7: 59-66.

Matsuoka, S. 2010: Great spotted woodpeckers Dendrocopos major detect variation in wood hardness before excavating nest holes. - Ornithological Science 9: 67-74.

Mazgajski, T. D. 1998: Nest-site characteristic of great spotted woodpecker Dendrocopos major in central Poland. - Pol.J. Ecol. 46: 33-41.

Mazgajski, T. D. 2002: Nesting phenology and breeding success in great spotted woodpecker Picoides major near Warsaw (central Poland). - Acta Orn. 37: 1-5.

Mazgajski, T. D. 2003: Nesting interaction between woodpeckers and starling - delayed commensalism, competition for nest sites or cavity kleptoparasitism? Forschungsbericht Nationalpark Berchtesgaden 48: 133-138.

Mazgajski, T. D. 2007a: Effect of old nest material on nest site selection and breeding parameters in secondary hole nesters. - Acta Orn. 42: 1-14.

Mazgajski, T. D. 2007b: Nest hole age decreases nest site attractiveness for the European starling Sturnus vulgaris. - Ornis Fennica 84: 32-38.

Moore, W. S. 1995: Northern flicker Colaptes auratus. - In: Poole, A. \& Gill, E. (eds.), The birds of North America no. 166. The Academy of Natural Sciences, Philadelphia, and American Ornithologists' Union, Washington, DC.

Møller, A. P. 1997: Parasitism and the evolution of host life history. - In: Clayton, D. H. \& Moore, J. (eds.), Hostparasite evolution: general principles and avian models: 
102-127. Oxford University Press, Oxford.

Newton, I. 1994: The role of nest-sites in limiting the numbers of hole-nesting birds: a review. - Biol. Cons. 70: 265-276.

Nilsson, J. A. \& Smith, H. G. 1988: Incubation feeding as a male tactic for early hatching. - Animal Behaviour 36: 641-647.

Nilsson, S. G., Johnsson, K. \& Tjernberg, M. 1991: Is the avoidance by black woodpeckers of old nest holes due to predators? - Animal Behaviour 41: 439-441.

Nordström, M. 2015: Evon retkeilyalueen hoito- ja käyttösuunnitelma. - Metsähallituksen luonnonsuojelujulkaisuja, Sarja C 133, Metsähallitus, Vantaa.

Pakkala, T., Hanski, I. \& Tomppo, E. 2002: Spatial ecology of the three-toed woodpecker in managed forest landscapes. - Silva Fennica 36: 279-288.

Pakkala, T., Pellikka, J. \& Lindén, H. 2003: Capercaillie Tetrao urogallus - a good candidate for an umbrella species in taiga forests. - Wildl. Biol. 9: 309-316.

Pakkala, T., Lakka, J., Nurmi, T., Piha, M., Piiroinen, J. \& Vepsäläinen, V. 2005: Pohjantikat radioseurannassa. Available at http://www.luomus.fi/fi/pohjantikat.

Pakkala, T., Kouki, J. \& Tiainen, J. 2006: Top predator and interference competition modify the existence, abundance and breeding success of a declining specialist species in a structurally complex environment. - Ann. Zool. Fennici 43: 137-164.

Pakkala, T., Lindén, A., Tiainen, J., Tomppo, E. \& Kouki, J. 2014: Indicators of forest biodiversity: which bird species predict high breeding bird assemblage diversity in boreal forests at multiple spatial scales? - Ann. Zool. Fennici 51: 457-476.

Pechacek, P. 1995: Spechte (Picidae) im Nationalpark Berchtesgaden. - Forschungsbericht Nationalpark Berchtesgaden 31: 1-183.

Pechacek, P. 2001: Tree selection for roosting and nesting in the three-toed woodpecker, and possible consequences for forest management practices. - In: Field, R., Warren, R. J., Okarma, H. \& Sievert, P. R. (eds.), Wildlife, land, and people: priorities for the 21st century, Proceedings of the Second International Wildife Management Congress: 15-18. The Wildlife Society, Bethesada.

Pechacek, P. 2004: Spacing behavior of Eurasian threetoed woodpeckers (Picoides tridactylus) during breeding season in Germany. - Auk 121: 58-67.

Pechacek, P. 2006: Breeding performance, natal dispersal, and nest site fidelity of the three-toed woodpecker in the German Alps. - Ann. Zool. Fennici 43: 165-176.

Pechacek, P. \& Krištín, A. 1993: Diet of woodpeckers, Piciformes in Berchtesgaden National Park. - Vogelwelt 114: $165-177$.

Pechacek, P. \& Krištín, A. 1996: Zur Ernährung und Nahrungsökologie des Dreizehenspechts Picoides tridactylus während der Nestlingszeit [Food and foraging ecology of the three-toed woodpecker Picoides tridactylus during the nestling period]. - Orn. Beob. 93: 259-266. [In German with English summary].

Pechacek, P. \& d'Oleire-Oltmanns, W. 2004: Habitat use of the three-toed woodpecker in central Europe during the breeding period. - Biol. Cons. 116: 333-341.
Perrins, C. M. 1970: The timing of birds' breeding season. Ibis 112: 242-255.

Rolstad, J., Rolstad, E. \& Sæteren, Ø. 2000: Black woodpecker nest sites: characteristics, selection, and reproductive success. - J. Wildl. Manage. 64: 1053-1066.

Ruge, K. 1974: Zur Biologie des Dreizehenspechtes Picoides tridactylus. 4. Brutbiologische und brutökologishe Daten aus der Schweiz. - Orn. Beob. 71: 303-311.

Ruge, K., Görze, H. J. \& Havelka, P. 1999: Der Dreizehenspecht (Picoides tridactylus) im Schwarzwald (Deutschland): Zusammenstellung brutbiologischer Daten. - Tichodroma 12: 116-121.

Ryssy, J. 2004: Pohjantikka pönttöpesijänä. - Suomenselän linnut 39: 139-141.

Saab, V. A., Dudley, J. \& Thompson, W. L. 2004: Factors influencing occupancy of nest cavities in recently burned forests. - Condor 106: 20-36.

Schifferli, A. \& Ziegeler, R. 1956: Begegnung mit dem Dreizehenspecht im Engadin. - Orn. Beob. 53: 1-5.

Short, L. L. 1979: Burdens of the picid hole-excavating habit. - Wilson Bull. 91: 16-28.

Short, L. L. 1982: Woodpeckers of the world. - Delaware Museum of Natural History, Monograph Series No. 4, Greenville, DE.

Smith, K. W. 1997: Nest site selection of the great spotted woodpecker Dendrocopos major in two oak woods in southern England and its implications for woodland management. - Biol. Cons. 80: 283-288.

Smith, K. W. 2006: The implications of nest site competition from starlings Sturnus vulgaris and the effect of spring temperatures on the timing and breeding performance of great spotted woodpeckers Dendrocopos major in southern England. - Ann. Zool. Fennici 43: 177-185.

Sollien, A., Nesholen, B. \& Fosseidengen, J. E. 1978: Observasjoner ved reit av tretåspett Picoides tridactylus. Cinclus 1: 58-64.

Sonerud, G. A. 1985: Nest hole shift in Tengmalm's owl Aegolius funereus as defence against nest predation involving long-term memory in the predator. $-J$. Anim. Ecol. 54: 179-192.

Sonerud, G. A. 1989: Reduced predation rate by pine martens on nests of Tengmalm's owl in relocated boxes. Animal Behaviour 37: 332-343.

Stenberg, I. 1996: Nest site selection of six woodpecker species. - Fauna norv. Ser. C 19: 21-38.

Svärdson, G. \& Durango, S. (eds.) 1950: Svenska djur. Fåglarna. - P. A. Norstedt \& Söners Förlag, Stockholm.

Tomảs, G., Merino, S., Moreno, J. \& Morales, J. 2007: Consequences of nest reuse for parasite burden and female health and condition in blue tits, Cyanistes caeruleus. Anim. Behav. 73: 805-814.

von Haartman, L. 1949: Der Trauerfliegenschnäpper. I. Ortstreue und Rassenbildung. - Acta Zool. Fennica 56: $1-104$.

von Haartman, L., Hildén, O., Linkola, P., Suomalainen, P. \& Tenovuo, R. 1963-1972: Pohjolan linnut värikuvin. Otava, Keuruu.

Wesołowski, T. 2011: "Lifespan" of woodpecker-made holes in a primeval temperate forest: a 30 year study. - For. 
Ecol. Manage. 262: 1846-1852.

Wesołowski, T. \& Stańska, M. 2001: High ectoparasite loads in hole nesting birds - a nest box bias? - J. Avian Biol. 32: 281-285.

Wiebe, K. L. 2001: Microclimate of tree cavity nests: Is it important for reproductive success in northern flickers? - Auk 118: 412-421.

Wiebe, K. L. 2003: Delayed timing as a strategy to avoid nest-site competition: testing a model using data from starlings and flickers. - Oikos 100: 291-298.

Wiebe, K. 2009: Nest site excavation does not reduce harmful effects of ectoparasitism: an experiment with a woodpecker, the northern flicker, Colaptes auratus. $-J$. Avian Biol. 40: 166-172.
Wiebe, K. L., Koenig, W. D. \& Martin, K. 2006: Evolution of clutch size in cavity-excavating birds: the nest site limitation hypothesis revisited. - Am. Nat. 167: 343-353.

Wiebe, K. L., Koenig, W. D. \& Martin, K. 2007: Costs and benefits of nest reuse versus excavation in cavity-nesting birds. - Ann. Zool. Fennici 44: 209-217.

Wiktander, U., Olsson, O. \& Nilsson, S. G. 2001: Annual and seasonal reproductive trends in the lesser spotted woodpecker Dendrocopos minor. - Ibis 143: 72-82.

Winkler, H. \& Christie, D. A. 2002: Family Picidae (Woodpeckers). - In: del Hoyo, J., Elliott, A. \& Sargatal, J. (eds.), Handbook of the birds of the world, vol. 7: Jacamars to woodpeckers: 296-555. Lynx Editions, Barcelona.

\section{Appendix}

\section{Inaccuracy and bias of three-toed woodpecker censuses and their effects on results}

The great majority of the three-toed woodpecker censuses were carried out by the first author with a thorough knowledge of the study area and potential territory sites of the species. However, with high and standardized census efficiency, even the nests with big nestlings are not always easy to detect. We consider that there are two cases where the variation in census efficiency can modify the results: (1) old nest cavities were observed more efficiently than new cavities because all previously observed old cavities were systematically checked and thus also multi-cavity trees were observed more efficiently than single-cavity trees; (2) nest cavities with big nestlings were more easily detected than those with small nestlings or eggs, not to mention especially those where nesting had been interrupted before the nestling period. The observed proportions of cavity and nest reuse may therefore be overestimates and proportions of fresh cavities in single-cavity trees underestimates. The risk that an occupied territory site remains undetected during the annual breeding season is most probably small, but the inefficiency of finding all active three-toed woodpecker nestings leads to underestimation of territory site quality. As active nestings that are interrupted before the nestling period are more probably missed than cavities with nestlings, nesting success levels are consequently overestimations and predation rates underestimations.

During the early years of the study, 1987-1993, eight active nestings were detected in old cavities whose excavation year was not known. All of them were clearly in cavities older than two years and they were classified as all other nestings in reused cavities. As the amount of these observations was very small as compared with the total observation number and they are not even included in the analyses of timing of nesting, we assume that possible inaccuracies in their classification are negligible as regards any results of the study.

As all cavities and nest trees found in previous years were systematically checked in each study year, the old nest cavities and multiple-cavity trees were more efficiently recorded than fresh cavities in new nest trees. The recorded proportions of cavity and tree reuse are therefore probably overestimations. It was difficult to correct directly the reuse proportions because we did not know the types and numbers of cavities that were not found. The mean quality of all territories weighted by occupancy was 0.66 (Table 3), and thus in $34 \%$ of all cases with at least territorial behaviour observed no active nesting was detected. At least in $15 \%$ of the cases with territorial behaviour, nesting did not proceed to active phase during the study period. So in the remaining $19 \%$ of the above-mentioned cases there was a possibility of an active nesting in the territory site that was not observed in the field. 
Assuming that all these non-observed active nestings were in fresh cavities of single-cavity nest trees, we get minimum values for cavity and tree reuse by multiplying the observed values by $0.66 /(0.66+$ $0.19)=0.78$. Thus the adjusted minimum values are (original values in parenthesis): $19.7 \%(25.3 \%)$ of nestings in reused cavities, nest reuse in $22.0 \%(28.2 \%)$ of all cavities and in $19.8 \%(25.4 \%)$ of all nest trees, the total proportion of multi-cavity trees $11.7 \%$ (15.0\%), proportion of cavities $24.8 \%$ $(31.8 \%)$ and nestings $31.4 \%$ (40.2\%) in multi-cavity trees.

In general, the time when big nestlings are in nests is the most efficient period to find three-toed woodpecker nests. In almost each of the study year there were some very late nestings which could be missed more often than early nestings, especially in fresh cavities of new nest trees. So there may be a small bias in the timing of nestings in fresh cavities which actually could on average be somewhat later than observed. This pattern makes the observed timing differences between fresh cavities and cavities reused in successive years and between nestings in single- and multi-cavity trees even greater, but on the other hand decreases the observed timing difference between fresh and lag-reused cavities (see Table 2). However, because the annual censuses were adjusted to the phenology of threetoed woodpecker's nesting time, and the numbers of very late nestings were quite small, we do not think that the inaccuracies of census results affect in a meaningful way the results of comparisons of nesting timing.

The possible bias resulting from missing some active nestings in the field causes territory quality measures of core and other territories to be underestimates. We can calculate the corrected values by multiplying the respective averages, 0.74 (core) and 0.50 (other) by $(0.78 / 0.66)$ arriving at 1.18 (cf. Table 3 and see above), and so we get corrected quality estimates of 0.87 (core territories) and 0.59 (other territories) that differ significantly from each other (test of two proportions: $z=2.77, p<0.01$ ). Thus the possible inaccuracy of censuses does not affect the observed general patterns of territory quality. 